
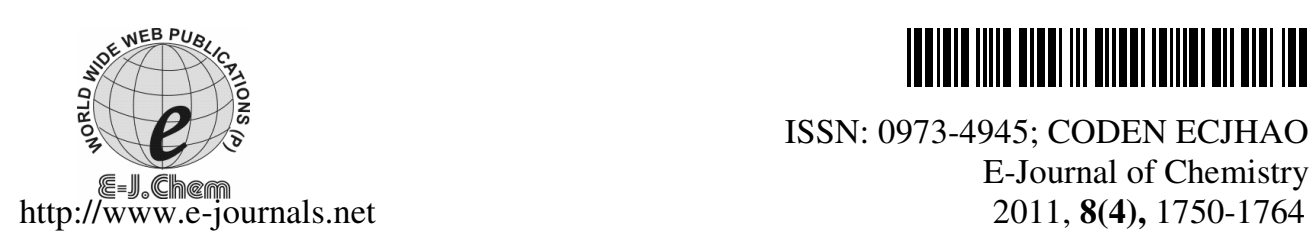

ISSN: 0973-4945; CODEN ECJHAO

E-Journal of Chemistry 2011, 8(4), 1750-1764

\title{
Coordination Modes of a Schiff Base Derived from Substituted 2-Aminothiazole with Chromium(III), Manganese(II), Iron(II), Cobalt(II), Nickel(II) and Copper(II) Metal Ions: Synthesis, Spectroscopic and Antimicrobial Studies
}

\author{
AMBIT THAKAR ${ }^{*}$, KRISHNAKANT JOSHI $^{\S}$, \\ KISHOR PANDYA and ARVIND PANCHOLI ${ }^{\S}$ \\ "Zydus Research Centre, Ahmedabad-382 210, India \\ ${ }^{\S}$ Department of Chemistry \\ Navjivan Science College, Dahod-389 151, India \\ Sir P.T. Science College, Modasa-383 315, India \\ krishnakant_joshi@yahoo.co.in
}

Received 9 November 2010; Accepted 21 January 2010

\begin{abstract}
Transition metal complexes of $\mathrm{Cr}(\mathrm{III}), \mathrm{Mn}(\mathrm{II}), \mathrm{Fe}(\mathrm{II}), \mathrm{Co}(\mathrm{II}), \mathrm{Ni}(\mathrm{II})$ and $\mathrm{Cu}(\mathrm{II})$ metal ions with general stoichiometry $\left[\mathrm{ML}_{2} \cdot 2 \mathrm{H}_{2} \mathrm{O}\right]$ and $\left[\mathrm{ML}_{3}\right]$, where $\mathrm{M}=\mathrm{Mn}$ (II), $\mathrm{Cr}(\mathrm{III}), \mathrm{Fe}(\mathrm{II}), \mathrm{Co}(\mathrm{II}), \mathrm{Ni}(\mathrm{II})$ and $\mathrm{Cu}(\mathrm{II}), \mathrm{L}=$ Schiff base derived from the condensation of 2-amino-4(4'-phenyl/methylphenyl)-5methyl-thiazole with 4-acetyl-1(3-chloro phenyl)-3-methyl-2-pyrazoline-5ones, have been synthesized and structurally characterized by elemental analysis, molar conductance measurements, magnetic susceptibility measurements and spectral techniques like IR, UV, ${ }^{1} \mathrm{H}$ NMR, ${ }^{13} \mathrm{C}$ NMR and Mass Spectra. All the complexes were found to be octahedral geometry. The ligand and its complexes have been screened for their antifungal and antibacterial activities against three fungi, i.e. Alternaria brassicae, Aspergillus niger and Fesarium oxysporum and two bacteria, i.e. Xanthomonas compestris and Pseudomonas aeruginosa.
\end{abstract}

Keywords: 2-Aminothiazole, Schiff base, Transition metals, Biological activities

\section{Introduction}

The thiazole ring is important in nature. It occurs, for example, in thiamine, a coenzyme required for the oxidative decarboxylation of $\alpha$-keto acids. A tetrahydrothiazole also appears 
in the skeleton of penicillin which is one of the first and still most important of the broadspectrum antibiotics. Thiazolamine are key intermediates for synthesizing many pharmaceuticals ${ }^{1}$. Some thiazolidone are valuable medicines ${ }^{2}$. It is obvious that compounds with the thiazole ring have potential biological activity. It is also known that some Schiff bases are effective antitumor drugs and antibacterials. Aminothiazoles are known to be ligands of the estrogen receptor and as a novel class of adenosine receptor antagonists ${ }^{3}$. We were interested in examining the biological activities of NO-donnor schiff's bases and their transition metal complexes, thus, in this article, we report the anti fungal and antibacterial activities of the Schiff base ligands 1-(3-chlorophenyl)-3methyl-4-(1-((5-methyl-4-phenylthiazol-2-yl)imino)ethyl)-1H-pyrazol-5-ol (L), 1-(3chlorophenyl)-3-methyl-4-(1-((5-methyl-4-(p-tolyl)thiazol-2-yl)imino)ethyl)-1H-pyrazol5-ol $\left(\mathbf{L}_{1}\right)$ and Its complexes with $\mathrm{Cr}(\mathrm{III}), \mathrm{Mn}(\mathrm{II}), \mathrm{Fe}(\mathrm{II}), \mathrm{Co}(\mathrm{II}), \mathrm{Ni}(\mathrm{II})$ and $\mathrm{Cu}(\mathrm{II})$ metal ions. The ligand and its complexes were characterized by physiochemical and spectral studies.

\section{Experimental}

All the chemicals used in the present study were of A.R. grade. 1,4-Dioxane and methanol (SD's fine chemical Ltd., Mumbai and Merck chemicals., Mumbai) were used without further purification. Absolute ethanol from alembic chemical works Co. Ltd., Baroda was used after distillation. $\mathrm{Cr}(\mathrm{III}), \mathrm{Mn}(\mathrm{II}), \mathrm{Co}(\mathrm{II}), \mathrm{Ni}(\mathrm{II}), \mathrm{Cu}(\mathrm{II})$ metal acetate and $\mathrm{Fe}(\mathrm{II})$ sulphate (SD's fine chemical Ltd, Qualigens-Glaxo, Mumbai and Merck chemicals., Mumbai) were used.

Melting points were taken in one side open capillaries on a melting point apparatus having model number VMP-D of a make VEEGO. The Mass spectra of all ligands were recorded on the instrument named LCMS-2010A of make Shimadzu. Carbon, Hydrogen and Nitrogen were estimated on a Thermo fisher (Thermo electron corporation Limited), Flash Elemental Analyzer-1112. The ${ }^{1} \mathrm{H}$ NMR and ${ }^{13} \mathrm{C}$ NMR spectra of all the ligands [in Deuterated Chloroform $\left(\mathrm{CDCl}_{3}\right)$ ] were recorded on a AVANCE-II 400 of make BRUKER spectro-photometer using TMS $\left[\left(\mathrm{CH}_{3}\right)_{4} \mathrm{Si}\right]$ as internal standard. The Infrared spectra of the ligands studied in the present work were recorded on the model FT-IR-8300 of Shimadzu in $\mathrm{KBr}$ (Zydus Research Center, Ahmedabad, India).

\section{Synthesis of the Schiff base ligands}

1-(3-Chlorophenyl)-3-methyl-4-(1-((5-methyl-4-phenylthiazol-2-yl)imino)ethyl)-1Hpyrazol-5-ol $(\boldsymbol{L})$

A hot solution of 4-acetyl-3-methyl-1-(3'-chlorophenyl)-2-pyrazolin-5-one (0.1 mol, 25 g) in methanol $(50 \mathrm{~mL})$ was slowly added drop wise to a hot solution of 2-amino-4phenyl-5-methyl thiazole $(0.1 \mathrm{~mol}, 19 \mathrm{~g})$ in methanol $(38 \mathrm{~mL})$. The resulting solution was refluxed for $7 \mathrm{~h}$ at $64^{\circ} \mathrm{C}$. The Solid compound precipitated out is filtered, washed with cold methanol and dried under vacuum oven at $50^{\circ} \mathrm{C}$. Yield: $28.6 \mathrm{~g}(68 \%)$. m.p.= $191{ }^{\circ} \mathrm{C}$. Anal. Calcd. For $\mathrm{C}_{22} \mathrm{H}_{19} \mathrm{ClN}_{4} \mathrm{OS}$ : C, 62.48; H, 4.53; N, 13.25; S, 7.58. Found: $\mathrm{C}$, 61.80; H, 4.44; N, 13.04; S, 7.82.

\section{1-(3-Chlorophenyl)-3-methyl-4-(1-((5-methyl-4-(p-tolyl)thiazol-2-yl)imino)ethyl)-} 1 H-pyrazol-5-ol $\left(\boldsymbol{L}_{1}\right)$

A hot solution of 4-acetyl-3-methyl-1-(3'-chlorophenyl)-2-pyrazolin-5-one (0.1 mol, $25 \mathrm{~g})$ 
in methanol $(50 \mathrm{~mL})$ was slowly added drop wise to a hot solution of 2-amino-4-(4'methylphenyl)-5-methyl thiazole $(0.1 \mathrm{~mol}, 20.4 \mathrm{~g})$ in methanol $(40 \mathrm{~mL})$. The resulting solution was refluxed for $7 \mathrm{~h}$ at $64{ }^{\circ} \mathrm{C}$. The Solid compound precipitated out is filtered, washed with cold methanol and dried under vacuum oven at $50^{\circ} \mathrm{C}$. Yield: $30.48 \mathrm{~g}(70 \%)$. M.P. $=178{ }^{\circ} \mathrm{C}$. Anal. Calcd. For $\mathrm{C}_{22} \mathrm{H}_{19} \mathrm{ClN}_{4} \mathrm{OS}: \mathrm{C}, 63.22 ; \mathrm{H}, 4.84 ; \mathrm{N}, 12.82 ; \mathrm{S}, 7.34$. Found: C, 61.53; H, 4.69; N, 12.37; S, 7.47.

\section{Synthesis of the metal complexes}

To hot solution of Schiff base ligands $(1 \mathrm{mmol})$ in dioxane $(15 \mathrm{~mL})$, a hot solution of corresponding metal salt like nitrate, chloride, acetate or sulphate $(1 \mathrm{mmol})$ in dioxane $(10 \mathrm{~mL})$ was added slowly with constant stirring. The resulting mixture was refluxed for 8 to $10 \mathrm{~h}$ at 85 to $90{ }^{\circ} \mathrm{C}$. On cooling the mixture overnight at $0{ }^{\circ} \mathrm{C}$, the colored product which separated out was filtered, washed with dioxane and dried under vacuum oven at $60{ }^{\circ} \mathrm{C}$.

\section{Results and Discussion}

The synthesized novel Schiff base ligands, 1-(3-chlorophenyl)-3-methyl-4-(1-((5-methyl4-phenylthiazol-2-yl)imino)ethyl)-1 $H$-pyrazol-5-ol (L) and 1-(3-chlorophenyl)-3-methyl4-(1-((5-methyl-4-( $p$-tolyl)thiazol-2-yl)imino)ethyl)-1H-pyra zol-5-ol ( $\left.\mathbf{L}_{\mathbf{1}}\right)$ (Scheme 1) forms stable complexes with $\mathrm{Cr}(\mathrm{III}), \mathrm{Mn}(\mathrm{II}), \mathrm{Fe}(\mathrm{II}), \mathrm{Co}(\mathrm{II}), \mathrm{Ni}(\mathrm{II})$ and $\mathrm{Cu}(\mathrm{II})$ metal ions. The analytical data of complexes, together with physical properties are given in Table 1 . The analytical data of the complexes correspond to the general stoichiometry $\left[\mathrm{ML}_{2} \cdot 2 \mathrm{H}_{2} \mathrm{O}\right]$ and $\left[\mathrm{ML}_{3}\right]$, where $\mathrm{M}=\mathrm{Cr}(\mathrm{III}), \mathrm{Mn}(\mathrm{II}), \mathrm{Fe}(\mathrm{II}), \mathrm{Co}(\mathrm{II}), \mathrm{Ni}(\mathrm{II})$ and $\mathrm{Cu}(\mathrm{II}), \mathrm{Ligand} \mathrm{L}=\mathrm{Schiff}$ base $\mathrm{L}$ and $\mathrm{L}_{1}$. The value of molar conductance $\left(\lambda_{\mathrm{M}}\right)$ of the complexes in DMSO indicates that the $\left[\mathrm{ML}_{2} .2 \mathrm{H}_{2} \mathrm{O}\right]$ and $\left[\mathrm{ML}_{3}\right]$ are non-electrolytes ${ }^{4}$. Magnetic moments lie in the range 1.81-1.89 B.M., 5.72-5.76 B.M., 4.96-5.02 B.M., 4.42-4.48 B.M., 2.89-2.95 B.M and 1.90-1.94 B.M., for $\mathrm{Cr}(\mathrm{III}), \mathrm{Mn}(\mathrm{II}), \mathrm{Fe}(\mathrm{II}), \mathrm{Co}(\mathrm{II}), \mathrm{Ni}(\mathrm{II})$ and $\mathrm{Cu}(\mathrm{II})$ complexes respectively.

\section{Mass spectra}

Mass spectra provide a vital clue for elucidation of compounds. The ESI mass spectrum of ligand $\mathrm{L}$ and $\mathrm{L}_{1}$ are given below. The spectrum in Figure 1 shows the molecular ion peak at $m / z=423.14$ and the isotopic peak at $m / z=424.99$ due to ${ }^{35} \mathrm{Cl}$ and ${ }^{37} \mathrm{Cl}$ isotopes of ligand $\mathrm{L}$. The spectrum in Figure 2 shows the molecular ion peak at $\mathrm{m} / z=437.13$ and the isotopic peak at $m / z=439.18$ due to ${ }^{35} \mathrm{Cl}$ and ${ }^{37} \mathrm{Cl}$ isotopes. In both the spectra the molecular ion peak is base peak and the intensity of these peaks reflects the stability and abundance of the ions 5 .

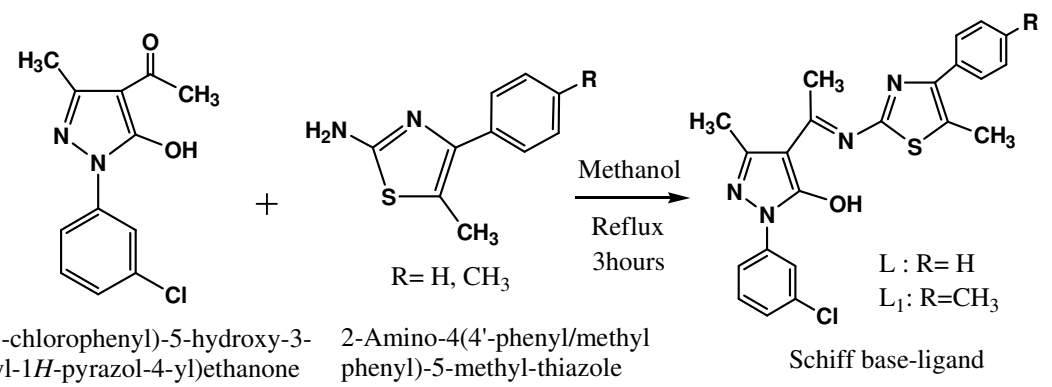

Scheme 1. Synthesis of ligand 
Table 1. Analytical data and physical properties of complexes

\begin{tabular}{|c|c|c|c|c|c|c|c|c|c|c|c|}
\hline \multirow[t]{2}{*}{ Complex } & \multirow[t]{2}{*}{$\mathrm{M} \mathrm{W}$} & \multirow[t]{2}{*}{ Color } & \multirow{2}{*}{$\stackrel{\mathrm{M} \mathrm{P},}{{ }^{\circ} \mathrm{C}}$} & \multirow{2}{*}{$\begin{array}{c}\lambda_{\mathrm{M}} \\
\Omega^{-1} \mathrm{~cm}^{-1} \\
\mathrm{~mol}^{-1}\end{array}$} & \multirow{2}{*}{$\begin{array}{l}\text { Yield, } \\
\%\end{array}$} & \multicolumn{6}{|c|}{$\begin{array}{l}\text { Elemental analysis data (\%) } \\
\text { Found (Calculated) }\end{array}$} \\
\hline & & & & & & $\mathrm{C}$ & $\mathrm{H}$ & $\mathrm{N}$ & $\mathrm{S}$ & $\mathrm{M}$ & $\mathrm{Cl}$ \\
\hline Ligand-L $\mathrm{C}_{22} \mathrm{H}_{19} \mathrm{ClN}_{4} \mathrm{OS}$ & 422.93 & Brown & 191 & - & 68 & $\begin{array}{c}61.80 \\
(62.48)\end{array}$ & $\begin{array}{c}4.44 \\
(4.53)\end{array}$ & $\begin{array}{c}13.04 \\
(13.25)\end{array}$ & $\begin{array}{c}7.82 \\
(7.58)\end{array}$ & - & $\begin{array}{c}8.11 \\
(8.38)\end{array}$ \\
\hline $\mathrm{Cr}(\mathrm{L})_{3} \mathrm{C}_{65} \mathrm{H}_{52} \mathrm{Cl}_{3} \mathrm{CrN}_{12} \mathrm{O}_{3} \mathrm{~S}_{3}$ & 1303.7 & Brown & $256^{*}$ & 11.94 & 65 & $\begin{array}{c}59.82 \\
(59.88)\end{array}$ & $\begin{array}{c}3.97 \\
(4.02)\end{array}$ & $\begin{array}{c}12.87 \\
(12.89)\end{array}$ & $\begin{array}{l}7.36 \\
(7.38)\end{array}$ & $\begin{array}{c}3.94 \\
(3.99)\end{array}$ & $\begin{array}{c}8.13 \\
(8.16)\end{array}$ \\
\hline $\begin{array}{c}\mathrm{Mn}(\mathrm{L})_{2} \cdot 2 \mathrm{H}_{2} \mathrm{O} \\
\mathrm{C}_{44} \mathrm{H}_{40} \mathrm{Cl}_{2} \mathrm{MnN}_{8} \mathrm{O}_{4} \mathrm{~S}_{2}\end{array}$ & 934.81 & Creamy & 239 & 12.12 & 70 & $\begin{array}{c}56.55 \\
(56.53)\end{array}$ & $\begin{array}{c}4.34 \\
(4.31)\end{array}$ & $\begin{array}{c}12.01 \\
(11.99)\end{array}$ & $\begin{array}{c}6.84 \\
(6.86)\end{array}$ & $\begin{array}{c}5.90 \\
(5.88)\end{array}$ & $\begin{array}{c}7.61 \\
(7.59)\end{array}$ \\
\hline $\mathrm{Fe}(\mathrm{L})_{2} \cdot 2 \mathrm{H}_{2} \mathrm{O} \mathrm{C}_{44} \mathrm{H}_{40} \mathrm{Cl}_{2} \mathrm{FeN}_{8} \mathrm{O}_{4} \mathrm{~S}_{2}$ & 935.72 & Brown & $224^{*}$ & 10.25 & 65 & $\begin{array}{c}56.50 \\
(56.48)\end{array}$ & $\begin{array}{c}4.33 \\
(4.31)\end{array}$ & $\begin{array}{c}11.94 \\
(11.98)\end{array}$ & $\begin{array}{c}6.87 \\
(6.85)\end{array}$ & $\begin{array}{c}5.99 \\
(5.97)\end{array}$ & $\begin{array}{l}7.59 \\
(7.58)\end{array}$ \\
\hline $\mathrm{Co}(\mathrm{L})_{2} \cdot 2 \mathrm{H}_{2} \mathrm{O} \mathrm{C}{ }_{44} \mathrm{H}_{40} \mathrm{Cl}_{2} \mathrm{CoN}_{8} \mathrm{O}_{4} \mathrm{~S}_{2}$ & 938.81 & $\begin{array}{c}\text { Dark } \\
\text { Brown }\end{array}$ & $263^{*}$ & 12.21 & 62 & $\begin{array}{c}56.32 \\
(56.29)\end{array}$ & $\begin{array}{c}4.28 \\
(4.29)\end{array}$ & $\begin{array}{c}11.97 \\
(11.94)\end{array}$ & $\begin{array}{c}6.85 \\
(6.83)\end{array}$ & $\begin{array}{c}6.29 \\
(6.28)\end{array}$ & $\begin{array}{c}7.45 \\
(7.55)\end{array}$ \\
\hline $\mathrm{Ni}(\mathrm{L})_{2} \cdot 2 \mathrm{H}_{2} \mathrm{O} \mathrm{C}{ }_{44} \mathrm{H}_{40} \mathrm{Cl}_{2} \mathrm{~N}_{8} \mathrm{NiO}_{4} \mathrm{~S}_{2}$ & 938.57 & Green & $281^{*}$ & 9.32 & 60 & $\begin{array}{c}56.34 \\
(56.31)\end{array}$ & $\begin{array}{c}4.32 \\
(4.30)\end{array}$ & $\begin{array}{c}11.92 \\
(11.94)\end{array}$ & $\begin{array}{c}6.87 \\
(6.83)\end{array}$ & $\begin{array}{c}6.24 \\
(6.25)\end{array}$ & $\begin{array}{c}7.59 \\
(7.55)\end{array}$ \\
\hline $\mathrm{Cu}(\mathrm{L})_{2} \cdot 2 \mathrm{H}_{2} \mathrm{O} \mathrm{C}{ }_{44} \mathrm{H}_{40} \mathrm{Cl}_{2} \mathrm{CuN}_{8} \mathrm{O}_{4} \mathrm{~S}_{2}$ & 943.42 & Brown & 210 & 11.32 & 64 & $\begin{array}{c}56.06 \\
(56.02)\end{array}$ & $\begin{array}{c}4.24 \\
(4.27)\end{array}$ & $\begin{array}{c}11.86 \\
(11.88)\end{array}$ & $\begin{array}{c}6.85 \\
(6.80)\end{array}$ & $\begin{array}{l}6.76 \\
(6.74)\end{array}$ & $\begin{array}{c}7.49 \\
(7.52)\end{array}$ \\
\hline Ligand- $\mathbf{L}_{1} \mathrm{C}_{23} \mathrm{H}_{21} \mathrm{ClN}_{4} \mathrm{OS}$ & 436.96 & Brown & 178 & - & 70 & $\begin{array}{c}61.53 \\
(63.22)\end{array}$ & $\begin{array}{c}4.69 \\
(4.84)\end{array}$ & $\begin{array}{c}12.37 \\
(12.82)\end{array}$ & $\begin{array}{l}7.47 \\
(7.34)\end{array}$ & - & $\begin{array}{c}8.08 \\
(8.11)\end{array}$ \\
\hline $\mathrm{Cr}\left(\mathrm{L}_{1}\right)_{3} \mathrm{C}_{68} \mathrm{H}_{58} \mathrm{Cl}_{3} \mathrm{CrN}_{12} \mathrm{O}_{3} \mathrm{~S}_{3}$ & 1345.8 & Brown & $266^{*}$ & 8.88 & 70 & $\begin{array}{c}60.72 \\
(60.69)\end{array}$ & $\begin{array}{c}4.36 \\
(4.34)\end{array}$ & $\begin{array}{c}12.47 \\
(12.49)\end{array}$ & $\begin{array}{c}7.12 \\
(7.15)\end{array}$ & $\begin{array}{c}3.85 \\
(3.86)\end{array}$ & $\begin{array}{c}8.01 \\
(7.90)\end{array}$ \\
\hline $\begin{array}{c}\mathrm{Mn}\left(\mathrm{L}_{1}\right)_{2} \cdot 2 \mathrm{H}_{2} \mathrm{O} \\
\mathrm{C}_{46} \mathrm{H}_{44} \mathrm{Cl}_{2} \mathrm{MnN}_{8} \mathrm{O}_{4} \mathrm{~S}_{2}\end{array}$ & 962.67 & Creamy & 222 & 10.34 & 65 & $\begin{array}{c}57.40 \\
(57.38)\end{array}$ & $\begin{array}{c}4.62 \\
(4.61)\end{array}$ & $\begin{array}{c}11.67 \\
(11.64)\end{array}$ & $\begin{array}{c}6.67 \\
(6.66)\end{array}$ & $\begin{array}{c}5.70 \\
(5.71)\end{array}$ & $\begin{array}{l}7.41 \\
(7.36)\end{array}$ \\
\hline $\begin{array}{c}\mathrm{Fe}\left(\mathrm{L}_{1}\right)_{2} \cdot 2 \mathrm{H}_{2} \mathrm{O} \\
\mathrm{C}_{46} \mathrm{H}_{44} \mathrm{Cl}_{2} \mathrm{FeN}_{8} \mathrm{O}_{4} \mathrm{~S}_{2}\end{array}$ & 963.77 & Brown & 231 & 9.32 & 60 & $\begin{array}{c}57.36 \\
(57.33)\end{array}$ & $\begin{array}{c}4.62 \\
(4.60)\end{array}$ & $\begin{array}{c}11.60 \\
(11.63)\end{array}$ & $\begin{array}{c}6.67 \\
(6.64)\end{array}$ & $\begin{array}{c}5.77 \\
(5.79)\end{array}$ & $\begin{array}{l}7.32 \\
(7.36)\end{array}$ \\
\hline $\begin{array}{c}\mathrm{Co}\left(\mathrm{L}_{1}\right)_{2} \cdot 2 \mathrm{H}_{2} \mathrm{O} \\
\mathrm{C}_{46} \mathrm{H}_{44} \mathrm{Cl}_{2} \mathrm{CoN}_{8} \mathrm{O}_{4} \mathrm{~S}_{2}\end{array}$ & 966.86 & $\begin{array}{c}\text { Dark } \\
\text { Brown }\end{array}$ & 252 & 10.24 & 67 & $\begin{array}{c}57.17 \\
(57.14)\end{array}$ & $\begin{array}{c}4.57 \\
(4.59)\end{array}$ & $\begin{array}{c}11.62 \\
(11.59)\end{array}$ & $\begin{array}{l}6.66 \\
(6.62)\end{array}$ & $\begin{array}{c}6.14 \\
(6.10)\end{array}$ & $\begin{array}{c}7.11 \\
(7.33)\end{array}$ \\
\hline $\mathrm{Ni}\left(\mathrm{L}_{1}\right)_{2} \cdot 2 \mathrm{H}_{2} \mathrm{O} \mathrm{C}{ }_{46} \mathrm{H}_{44} \mathrm{Cl}_{2} \mathrm{~N}_{8} \mathrm{NiO}_{4} \mathrm{~S}_{2}$ & 966.62 & Green & $276^{*}$ & 10.35 & 65 & $\begin{array}{c}57.19 \\
(57.16)\end{array}$ & $\begin{array}{c}4.62 \\
(4.59)\end{array}$ & $\begin{array}{c}11.57 \\
(11.59)\end{array}$ & $\begin{array}{c}6.66 \\
(6.63)\end{array}$ & $\begin{array}{c}6.04 \\
(6.07)\end{array}$ & $\begin{array}{l}7.29 \\
(7.34)\end{array}$ \\
\hline $\mathrm{Cu}\left(\mathrm{L}_{1}\right)_{2} \cdot 2 \mathrm{H}_{2} \mathrm{O} \mathrm{C}_{46} \mathrm{H}_{44} \mathrm{Cl}_{2} \mathrm{CuN}_{8} \mathrm{O}_{4} \mathrm{~S}_{2}$ & 971.47 & Brown & 229 & 12.45 & 62 & $\begin{array}{c}56.88 \\
(56.87) \\
\end{array}$ & $\begin{array}{c}4.59 \\
(4.57) \\
\end{array}$ & $\begin{array}{c}11.50 \\
(11.53)\end{array}$ & $\begin{array}{c}6.59 \\
(6.60) \\
\end{array}$ & $\begin{array}{c}6.56 \\
(6.54) \\
\end{array}$ & $\begin{array}{c}7.22 \\
(7.30) \\
\end{array}$ \\
\hline
\end{tabular}




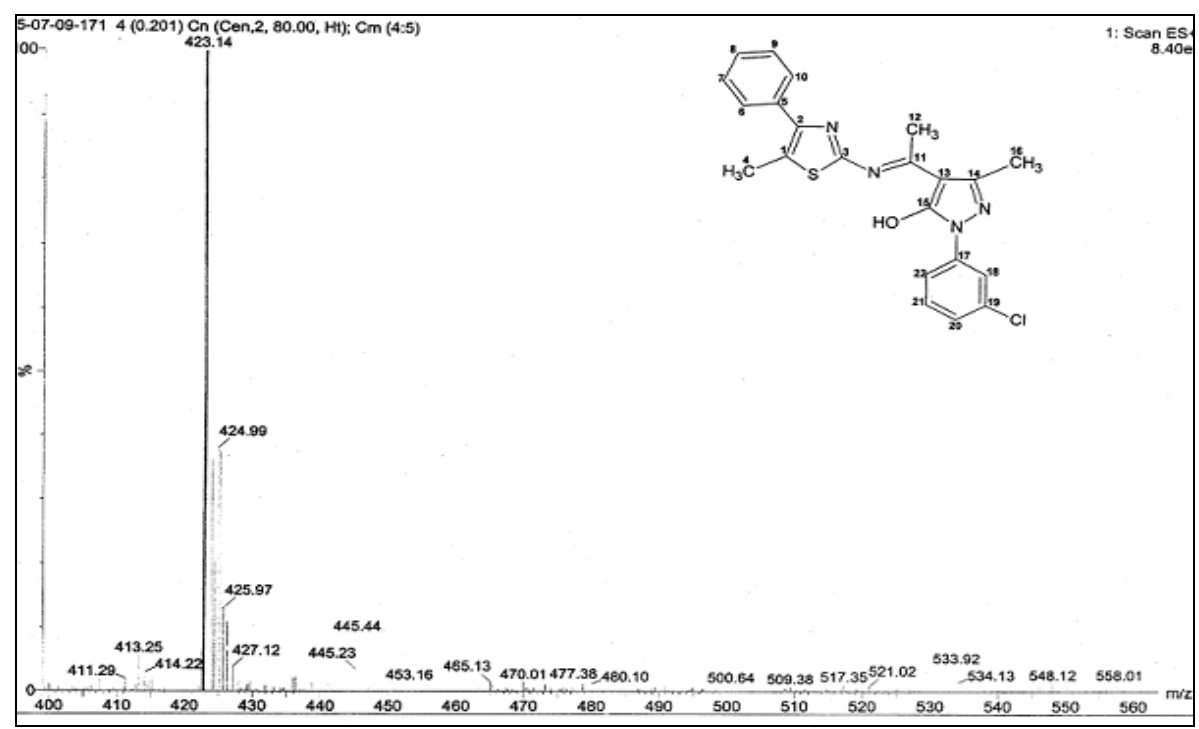

Figure 1. Mass spectrum of the ligand L

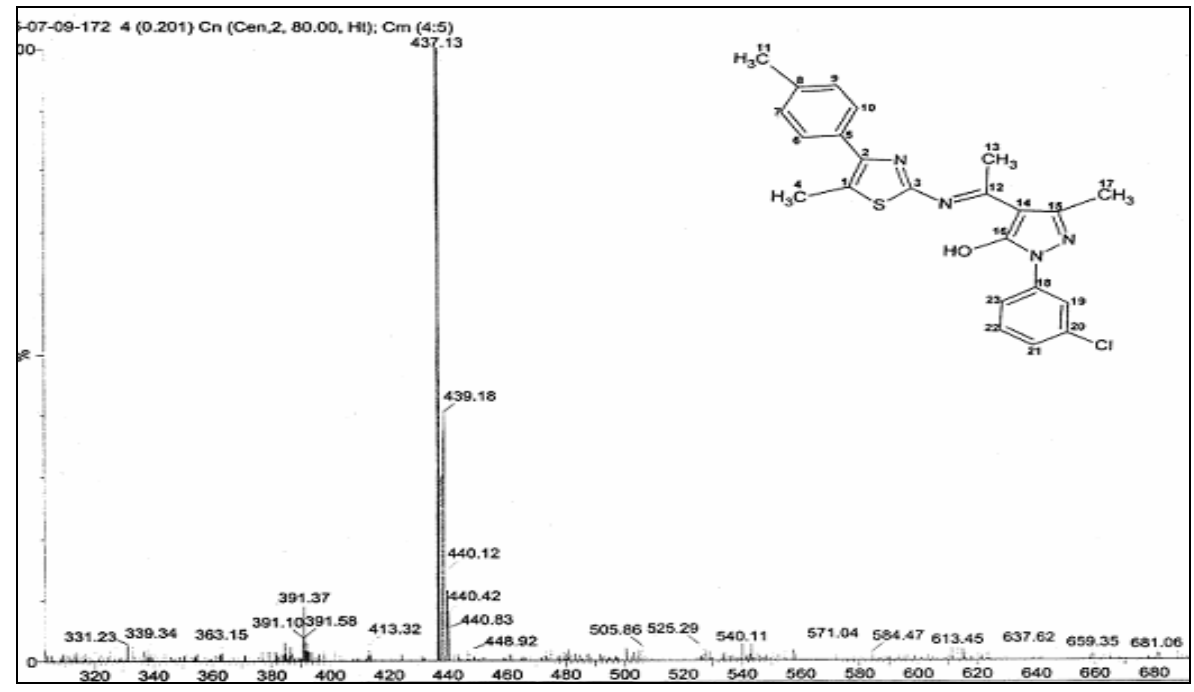

Figure 2. Mass spectrum of the ligand $\mathrm{L}_{1}$

\section{NMR spectra}

NMR data of ligand $\mathrm{L}$ are given in Table 2. Its ${ }^{1} \mathrm{H}$ NMR spectrum (Figure 3) displays three singlets at ca. $\delta 2.43-2.86 \mathrm{ppm}\left(\mathrm{s}, 9 \mathrm{H}, 3 \mathrm{H}_{3} \mathrm{C}-\mathrm{C}\right)$ due to the nine protons of three methyl groups, at ca. $\delta 7.12-8.08 \mathrm{ppm}(\mathrm{m}, 9 \mathrm{H}$, aromatic) due to the protons of two phenyl rings and a singlet at ca. $\delta 13.75 \mathrm{ppm}(\mathrm{s}, 1 \mathrm{H},-\mathrm{OH})$ due to the alcohol and NMR data of ligand $\mathrm{L}_{1}$ are given in Table 3. Its ${ }^{1} \mathrm{H}$ NMR spectrum (Figure 4) displays four singlets at ca. $\delta 2.36-2.86$ ppm $\left(\mathrm{s}, 12 \mathrm{H}, 4 \mathrm{H}_{3} \mathrm{C}-\mathrm{C}\right)$ due to the twelve protons of four methyl groups, at ca. $\delta 7.12-8.08$ ppm $(\mathrm{m}, 9 \mathrm{H}$, aromatic) due to the protons of two phenyl rings and a singlet at ca. $\delta 13.73$ ppm (s, 1H, -OH) due to the alcohol ${ }^{6}$. 
Table 2. The NMR data of Schiff base ligand L

\begin{tabular}{|c|c|c|c|}
\hline \multicolumn{2}{|c|}{${ }^{1} \mathrm{H}$ NMR } & \multicolumn{2}{|r|}{${ }^{13} \mathrm{C}$ NMR } \\
\hline$\delta, \mathrm{ppm}$ & Assignment & $\delta, \mathrm{ppm}$ & Assignment \\
\hline $2.43-2.86$ & $\mathrm{~s}, 9 \mathrm{H}, 3 \mathrm{H}_{3} \mathrm{C}-\mathrm{C}$ & 12.72 & Primary Carbon C(4) \\
\hline $7.12-8.08$ & m, 9H, Ar & 17.87 & Primary Carbon C(16) \\
\hline 13.75 & $\mathrm{~s}, 1 \mathrm{H},-\mathrm{OH}$ & 18.31 & Primary Carbon C(12) \\
\hline & & 102.96 & $\mathrm{C}=\mathrm{C}$ of Pyrazolone $\mathrm{C}(13)$ \\
\hline & & $116.94-128.55$ & Tertiary Aromatic Carbon \\
\hline & & $129.91-134.63$ & $\begin{array}{l}\text { Quaternary Aromatic Carbon } \\
C(5), C(19), C(17)\end{array}$ \\
\hline & & 139.79 & $\mathrm{C}=\mathrm{C}$ of thiazole ring $\mathrm{C}(1)$ \\
\hline & & 148.48 & $\mathrm{C}=\mathrm{N}$ of Pyrazolone $\mathrm{C}(14)$ \\
\hline & & 148.51 & $\mathrm{C}=\mathrm{C}$ of thiazole ring $\mathrm{C}(2)$ \\
\hline & & 154.94 & C-OH of Pyrazolone C(15) \\
\hline & & 161.49 & $\mathrm{C}=\mathrm{N}$ of Azomethine $\mathrm{C}(11)$ \\
\hline & & 165.51 & $\mathrm{C}=\mathrm{N}$ of thiazole ring $\mathrm{C}(3)$ \\
\hline
\end{tabular}

Table 3. The NMR data of Schiff base ligand $\mathrm{L}_{1}$

\begin{tabular}{|c|c|c|c|}
\hline \multicolumn{2}{|c|}{${ }^{1} \mathrm{H}$ NMR } & \multicolumn{2}{|r|}{${ }^{13} \mathrm{C}$ NMR } \\
\hline$\delta, \mathrm{ppm}$ & Assignment & $\delta, \mathrm{ppm}$ & Assignment \\
\hline $2.36-2.86$ & $\mathrm{~s}, 12 \mathrm{H}, 3 \mathrm{H}_{3} \mathrm{C}-\mathrm{C}$ & 12.73 & Primary Carbon C(4) \\
\hline $7.12-8.08$ & $\mathrm{~m}, 8 \mathrm{H}, \mathrm{Ar}$ & 17.88 & Primary Carbon C(17) \\
\hline 13.73 & $\mathrm{~s}, 1 \mathrm{H},-\mathrm{OH}$ & 18.31 & Primary Carbon C(13) \\
\hline & & 21.40 & Primary Carbon C(11) \\
\hline 11 & & 102.91 & $\mathrm{C}=\mathrm{C}$ of Pyrazolone $\mathrm{C}(14)$ \\
\hline & & $\begin{array}{l}116.97- \\
129.26\end{array}$ & Tertiary Aromatic Carbon \\
\hline & & $\begin{array}{l}129.91- \\
137.86\end{array}$ & $\begin{array}{l}\text { Quaternary Aromatic } \\
\text { Carbon } C(5), C(8), C(20) \text {, } \\
C(18)\end{array}$ \\
\hline & & 139.83 & $\mathrm{C}=\mathrm{C}$ of thiazole ring $\mathrm{C}(1)$ \\
\hline & & 148.29 & $\mathrm{C}=\mathrm{N}$ of Pyrazolone $\mathrm{C}(15)$ \\
\hline & & 148.60 & $\mathrm{C}=\mathrm{C}$ of thiazole ring $\mathrm{C}(2)$ \\
\hline & & 154.79 & $\mathrm{C}-\mathrm{OH}$ of Pyrazolone $\mathrm{C}(16)$ \\
\hline & & 161.54 & $\mathrm{C}=\mathrm{N}$ of Azomethine $\mathrm{C}(12)$ \\
\hline & & 165.53 & $\mathrm{C}=\mathrm{N}$ of thiazole ring $\mathrm{C}(3)$ \\
\hline
\end{tabular}

The ${ }^{13} \mathrm{C}$ NMR spectrum of ligand L (Figure 5) displays the signals corresponding to the different non-equivalent carbon atoms at different values of $\delta$ as follows: at ca. $\delta 12.72 \mathrm{ppm}$, $\delta 17.87 \mathrm{ppm}$ and $\delta 18.31 \mathrm{ppm}\left(\mathrm{H}_{3} \mathrm{C}-\mathrm{C}\right)$ corresponding to carbon atoms of methyl groups; at ca. $\delta 102.96 \mathrm{ppm}(\mathrm{C}=\mathrm{C})$ due to carbon atom of pyrazolone ring; at ca. $\delta 116.97-134.36 \mathrm{ppm}$ due to aromatic carbon atoms; at ca. $\delta 139.79(\mathrm{C}=\mathrm{C})$ due to carbon atom of thiazole ring; at ca. $\delta 148.48(\mathrm{C}=\mathrm{N})$ due to carbon atom of pyrazolone ring; at ca. $\delta 148.51(\mathrm{C}=\mathrm{C})$ due to carbon atom of thiazole ring; at ca. $\delta 154.94(\mathrm{C}-\mathrm{OH})$ due to carbon atom of pyrazolone ring; at ca. $\delta 161.49(\mathrm{C}=\mathrm{N})$ due to carbon atom of azomethine and at ca. $\delta 165.51(\mathrm{C}=\mathrm{N})$ due to carbon atom of thiazole ring. In the same manner ${ }^{13} \mathrm{C}-\mathrm{NMR}$ spectrum of ligand $\mathrm{L}_{1}$ (Figure 6) describe in Table 3. 


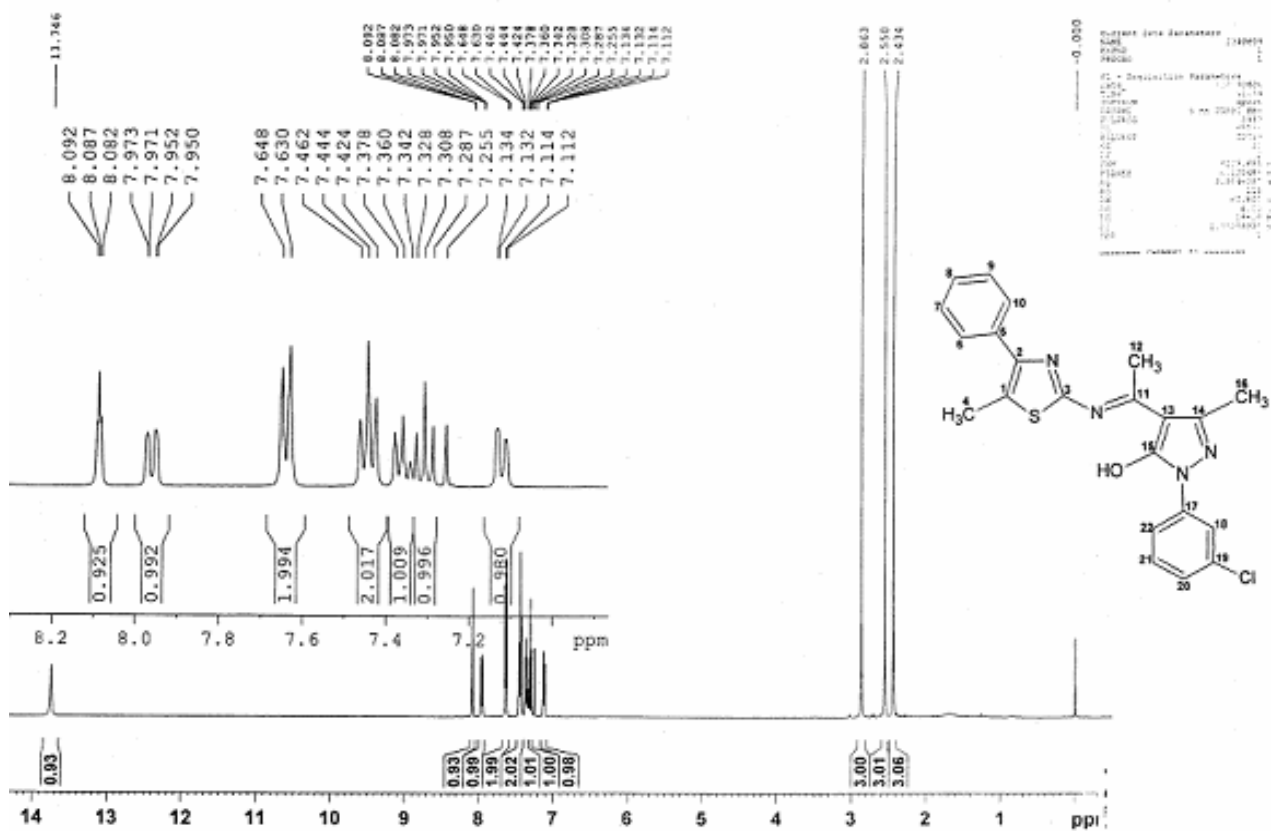

Figure 3. ${ }^{1} \mathrm{H}$ NMR spectrum of the ligand L

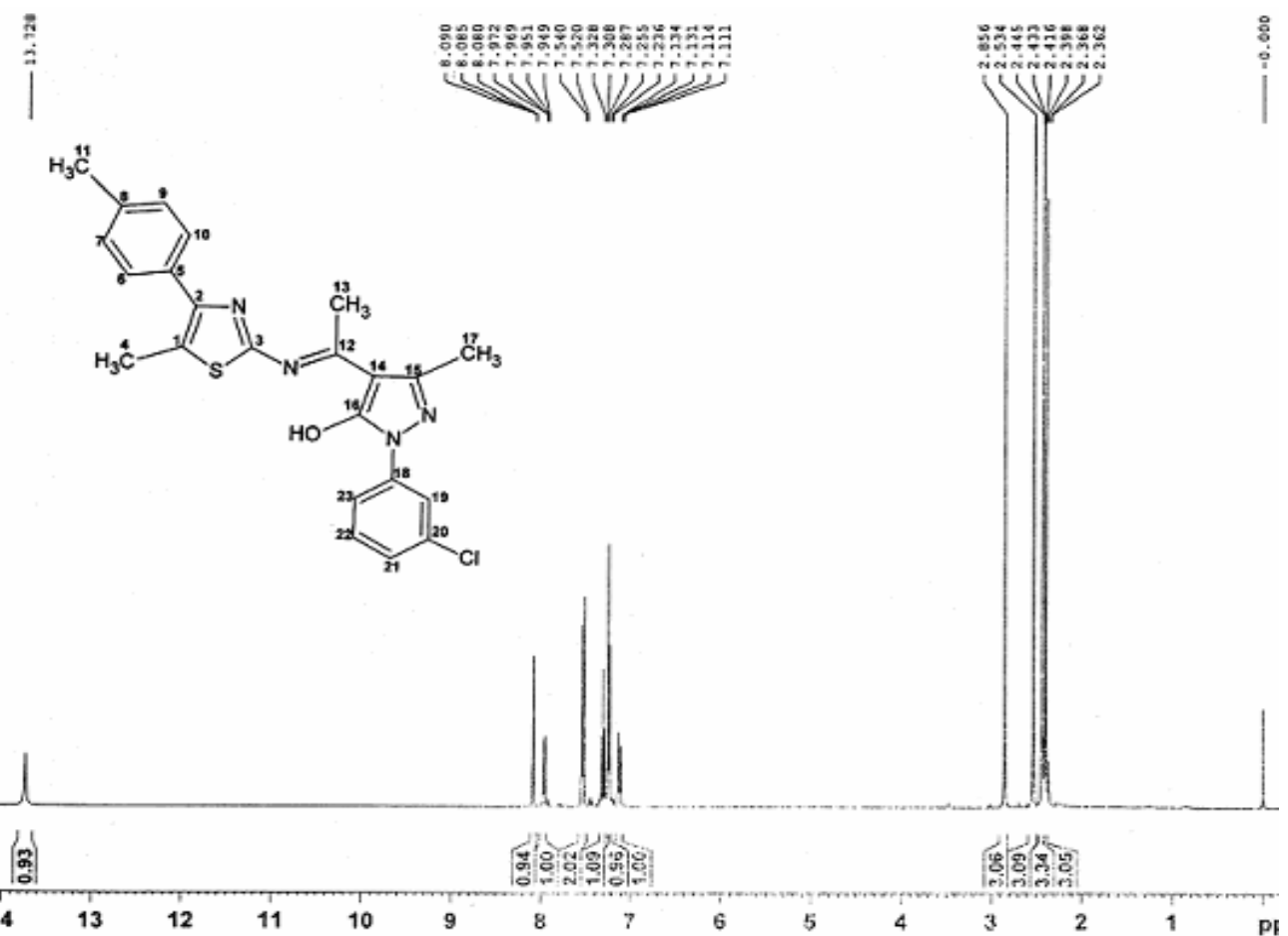

Figure 4. ${ }^{1} \mathrm{H}$ NMR spectrum of the ligand $\mathrm{L}_{1}$ 


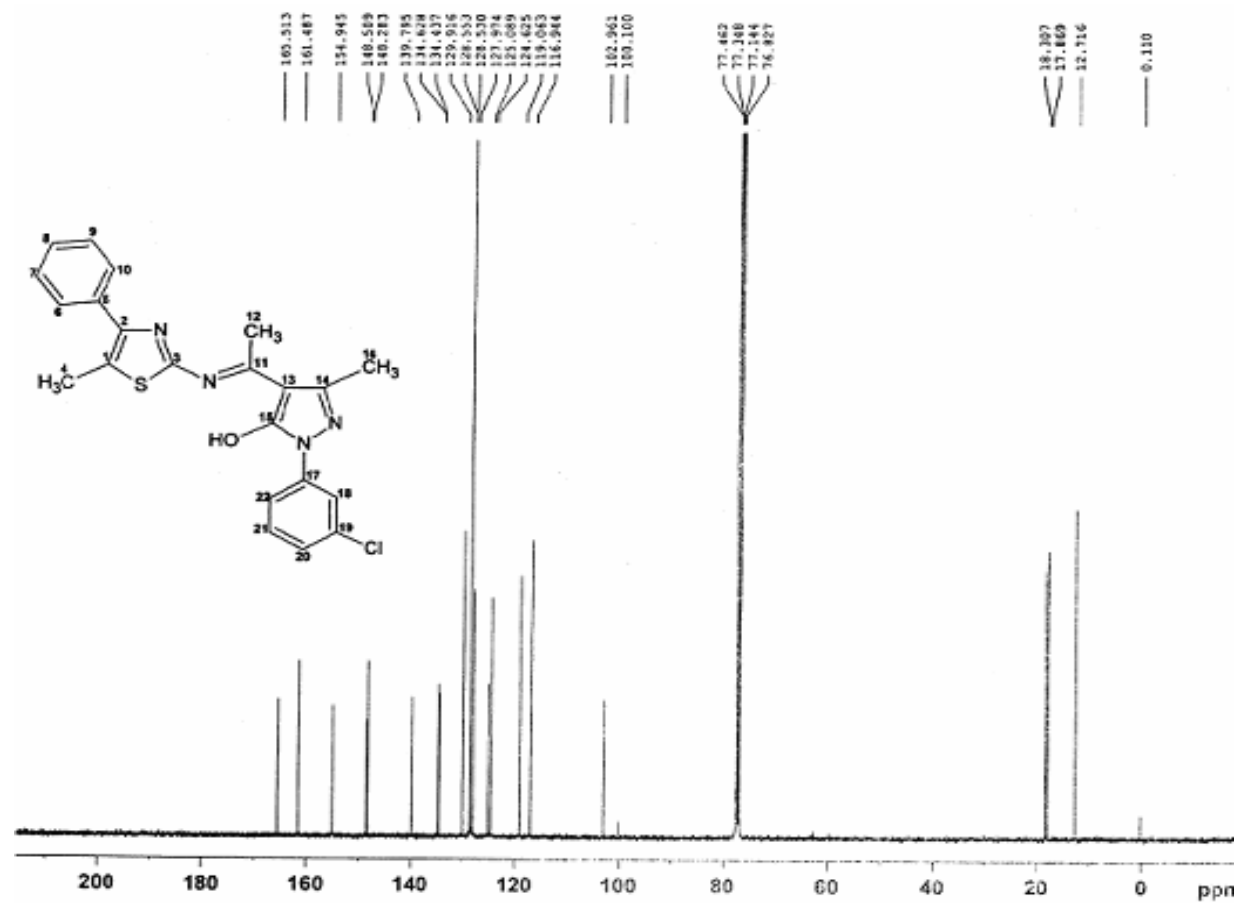

Figure 5. ${ }^{13} \mathrm{C}$ NMR spectrum of the ligand L

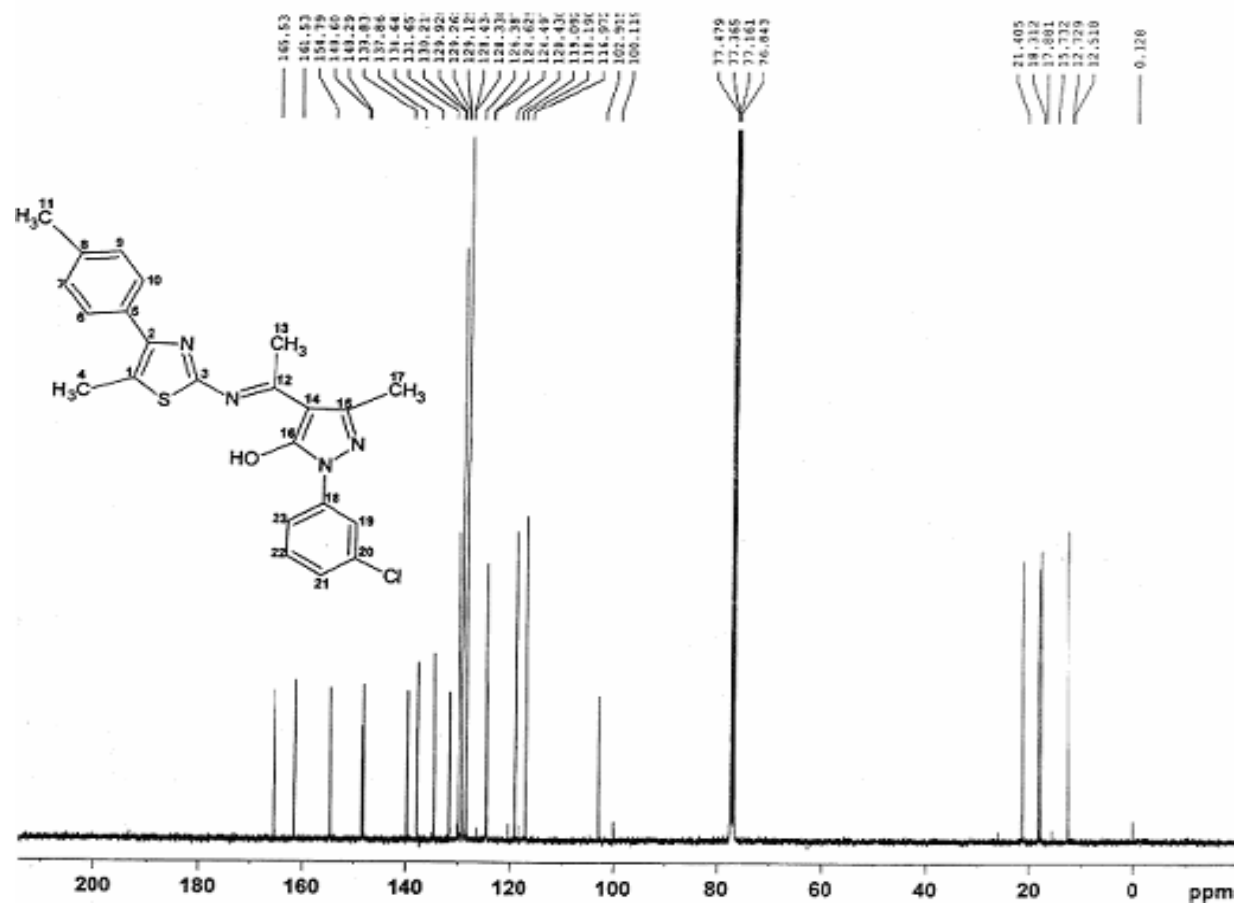

Figure 6. ${ }^{13} \mathrm{C}$ NMR spectrum of the ligand $\mathrm{L}_{1}$ 


\section{IR spectra}

Selected IR bands of the ligand and its complexes are listed in Table 4. The infrared spectra of the both ligands $\mathrm{L}_{\text {and }} \mathrm{L}_{1}$ show $v_{\mathrm{O}-\mathrm{H}}$ (weakly H-bonded) at $3345 \mathrm{~cm}^{-1}$ and $3320 \mathrm{~cm}^{-1}$ respectively ${ }^{7}$. The absence of this band in all the metal complexes indicates the removal of proton of hydroxyl group of pyrazolin ring during the chelation. This is further supported by the shift of C-O frequency from $\sim 1315 \mathrm{~cm}^{-1}$ (in ligand) to the higher frequency $1330-1400 \mathrm{~cm}^{-1}$ (in complexes) $)^{8}$. The sharp intense band at $1626 \mathrm{~cm}^{-1}$ and $1627 \mathrm{~cm}^{-1}$ respectively in the ligands can be assigned to $v_{\mathrm{C}=\mathrm{N}}$ (azomethine). A downward shift $\left(\Delta v=15-35 \mathrm{~cm}^{-1}\right)$ in $v_{\mathrm{C}=\mathrm{N}}$ (azomethine) is observed upon coordination indicating that the nitrogen of azomethine group is involved in coordination. All the complexes show broad band in the region $3250 \mathrm{~cm}^{-1}$ to $3500 \mathrm{~cm}^{-1}$ which may be assigned to $v{ }_{\text {O-H }}$ of coordinated water ${ }^{9}$. To account for the octahedral stereochemistry of the metal complexes, the coordination of two water molecules is expected.

Table 4. Selected IR bands of Schiff base ligand $\mathrm{L}$, ligand $\mathrm{L}_{1}$ and its complexes

\begin{tabular}{|c|c|c|c|c|c|c|c|}
\hline \multirow{2}{*}{$\begin{array}{l}\text { Ligand } \\
\text { Ligand L }\end{array}$} & \multicolumn{6}{|c|}{ Metal complexes of } & \multirow{2}{*}{ Assignment } \\
\hline & $\mathrm{Cr}(\mathrm{III})$ & $\mathrm{Mn}(\mathrm{II})$ & $\mathrm{Fe}(\mathrm{II})$ & $\mathrm{Co}(\mathrm{II})$ & $\mathrm{Ni}(\mathrm{II})$ & $\mathrm{Cu}(\mathrm{II})$ & \\
\hline 3345 (w,br) & - & - & - & - & - & - & $v_{\mathrm{O}-\mathrm{H}}($ Enolic $)$ \\
\hline- & - & 3431 & 3371 & 3423 & 3404 & 3358 & $v_{\mathrm{O}-\mathrm{H}}($ Coordinated water $)$ \\
\hline $1626(\mathrm{~s}, \mathrm{~s})$ & 1604 & 1613 & 1614 & 1600 & 1604 & 1591 & $v_{\mathrm{C}=\mathrm{N}}($ Azomethine $)$ \\
\hline $1587(\mathrm{~s}, \mathrm{~s})$ & 1582 & 1589 & 1591 & 1583 & 1590 & 1586 & $v_{\mathrm{C}=\mathrm{N}}($ Pyrazolin $)$ \\
\hline $1516(\mathrm{~s}, \mathrm{~s})$ & 1535 & 1520 & 1533 & 1535 & 1520 & 1520 & $v_{\mathrm{C}=\mathrm{C}}$ (Phenyl ring) \\
\hline $1477(\mathrm{~s}, \mathrm{~s})$ & 1487 & 1485 & 1492 & 1473 & 1490 & 1495 & Thiazole ring stretching \\
\hline $1452(\mathrm{~s}, \mathrm{~s})$ & 1442 & 1431 & 1444 & 1411 & 1454 & 1467 & Pyrazolin ring stretching \\
\hline $1315(\mathrm{~s}, \mathrm{~s})$ & 1383 & 1381 & 1383 & 1354 & 1346 & 1330 & $\mathrm{v}_{\mathrm{C}-\mathrm{O}}($ Enol $)$ \\
\hline $1265(\mathrm{~m}, \mathrm{~s})$ & - & - & - & - & - & - & $\delta_{\mathrm{O}-\mathrm{H}}($ Enol $)$ \\
\hline $1120(\mathrm{~m}, \mathrm{br})$ & 1120 & 1124 & 1128 & 1190 & 1120 & 1120 & Pyrazolin ring breathing \\
\hline- & - & 883 & 819 & 871 & 801 & 846 & $v_{\mathrm{O}-\mathrm{H}}($ coordinated water) \\
\hline 767 (m,br) & 758 & 731 & 756 & 756 & 729 & 709 & C-Cl Stretch \\
\hline- & 657 & 657 & 653 & 623 & 682 & 640 & $v_{\mathrm{M}-\mathrm{O}}$ \\
\hline- & 520 & 582 & 510 & 518 & 530 & 590 & $v_{\mathrm{M}-\mathrm{N}}$ \\
\hline Ligand $\mathrm{L}_{1}$ & \multicolumn{6}{|c|}{ Metal complexes } & Assignment \\
\hline $3320(\mathrm{w}, \mathrm{br})$ & - & - & - & - & - & - & $v_{\mathrm{O}-\mathrm{H}}($ Enolic $)$ \\
\hline- & - & 3396 & 3346 & 3423 & 3443 & 3246 & $v_{\mathrm{O}-\mathrm{H}}($ Coordinated water $)$ \\
\hline $1627(\mathrm{~s}, \mathrm{~s})$ & 1600 & 1622 & 1609 & 1602 & 1606 & 1610 & $v_{\mathrm{C}=\mathrm{N}}($ Azomethine $)$ \\
\hline $1589(\mathrm{~s}, \mathrm{~s})$ & 1583 & 1582 & 1585 & 1586 & 1585 & 1588 & $v_{\mathrm{C}=\mathrm{N}}($ Pyrazolin $)$ \\
\hline $1527(\mathrm{~s}, \mathrm{~s})$ & 1533 & 1520 & 1532 & 1521 & 1520 & 1530 & $v_{\mathrm{C}=\mathrm{C}}($ Phenyl ring $)$ \\
\hline $1498(\mathrm{~s}, \mathrm{~s})$ & 1494 & 1504 & 1501 & 1496 & 1483 & 1502 & Thiazole ring stretching \\
\hline $1479(\mathrm{~s}, \mathrm{~s})$ & 1475 & 1477 & 1479 & 1465 & 1442 & 1425 & Pyrazolin ring stretching \\
\hline $1310(\mathrm{~s}, \mathrm{~s})$ & 1323 & 1357 & 1332 & 1327 & 1354 & 1355 & $v_{\mathrm{C}-\mathrm{O}}($ Enol $)$ \\
\hline $1209(\mathrm{~m}, \mathrm{~s})$ & - & - & - & - & - & - & $\delta_{\mathrm{O}-\mathrm{H}}(\mathrm{Enol})$ \\
\hline $1178(\mathrm{~m}, \mathrm{br})$ & 1187 & 1141 & 1101 & 1111 & 1176 & 1141 & Pyrazolin ring breathing \\
\hline- & - & 829 & 833 & 829 & 821 & 806 & $v_{\mathrm{O}-\mathrm{H}}($ coordinated water $)$ \\
\hline 759 (m,br) & 717 & 727 & 735 & 780 & 775 & 738 & C-Cl Stretching \\
\hline- & 673 & 605 & 690 & 667 & 682 & 623 & $v_{\mathrm{M}-\mathrm{O}}$ \\
\hline- & 590 & 509 & 565 & 516 & 468 & 484 & $v_{\mathrm{M}-\mathrm{N}}$ \\
\hline
\end{tabular}


The bands in the range between $450 \mathrm{~cm}^{-1}$ to $590 \mathrm{~cm}^{-1}$ may be due to metal-nitrogen stretching vibration ${ }^{10}$ of $\mathrm{Cr}(\mathrm{III}), \mathrm{Mn}(\mathrm{II}), \mathrm{Fe}(\mathrm{II}), \mathrm{Co}(\mathrm{II}), \mathrm{Ni}(\mathrm{II})$ and $\mathrm{Cu}(\mathrm{II})$ complexes. The bands in the range between $600 \mathrm{~cm}^{-1}$ to $690 \mathrm{~cm}^{-1}$ may be due to metal-oxygen stretching vibration $^{11}$ of $\mathrm{Cr}(\mathrm{III}), \mathrm{Mn}(\mathrm{II}), \mathrm{Fe}(\mathrm{II}), \mathrm{Co}(\mathrm{II}), \mathrm{Ni}(\mathrm{II})$ and $\mathrm{Cu}(\mathrm{II})$ complexes. A less intense band between $1610 \mathrm{~cm}^{-1}-1560 \mathrm{~cm}^{-1}$ in the spectrum of ligand may be assigned to $v_{\mathrm{C}=\mathrm{N}}$ (pyrazolin ring) ${ }^{12}$. All the metal complexes do not show shifting in $v_{\mathrm{C}=\mathrm{N}}$ compared to its respective ligands. This suggests that the nitrogen atom of the ring has not participated in the chelation. However, in water containing chelates, this band is observed as a broad. This may be due to coupling of the bending mode of coordinated water molecules with $v_{\mathrm{C}=\mathrm{N}}{ }^{13}$.

\section{Electronic spectra}

The electronic spectra of the complexes were recorded in DMSO solution. Both the ligands show two absorption bands (Figure 7) at $37313 \mathrm{~cm}^{-1}, 26385 \mathrm{~cm}^{-1}$ and (Figure 8) $37453 \mathrm{~cm}^{-1}$, $26246 \mathrm{~cm}^{-1}$ respectively. No absorption was observed in the visible region for any of the ligands. In the absence of Quantum mechanical calculation, it is not possible to assign the absorption bands to definite electronic transitions with complete certainty. However, it appears reasonable to assign the bands to $\pi \rightarrow \pi^{*}$ transitions.

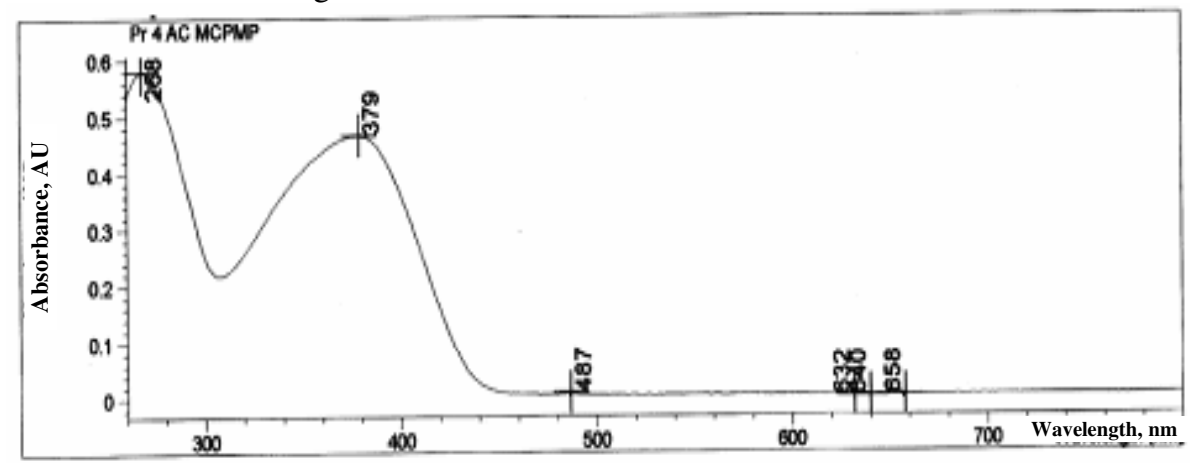

Figure 7. UV spectra of the ligand L

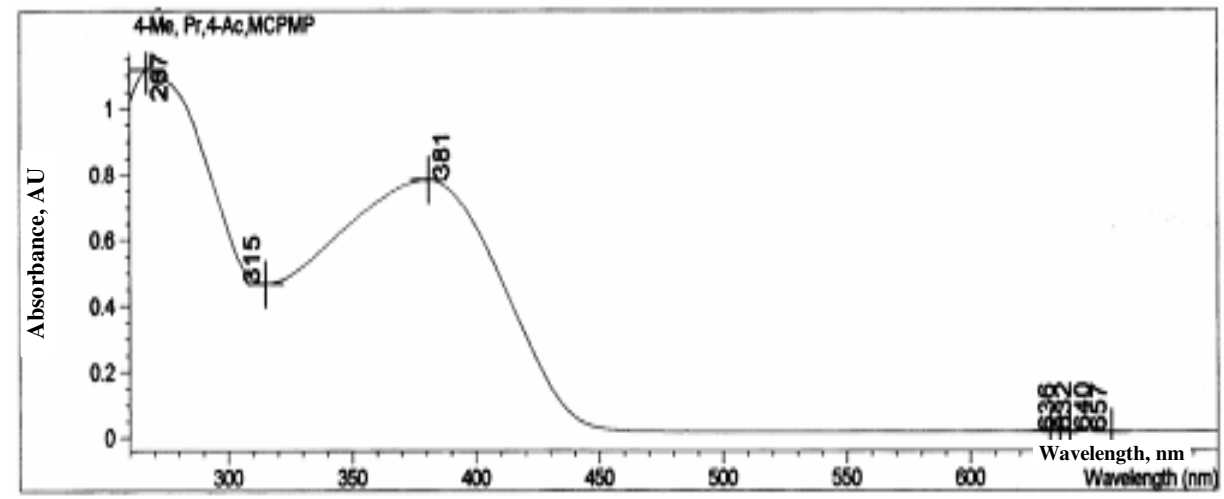

Figure 8. UV spectra of the ligand $\mathrm{L}_{1}$

The electronic spectra of chromium(III) complexes display the d-d transition bands in the region $23,000-15,900 \mathrm{~cm}^{-1}$ and $29,100-24,500 \mathrm{~cm}^{-1}$. This transitions may be assigned to the ${ }^{4} \mathrm{~A}_{2 \mathrm{~g}} \rightarrow{ }^{4} \mathrm{~T}_{2 \mathrm{~g}}\left(\mathrm{v}_{1}\right)$ and ${ }^{4} \mathrm{~A}_{2 \mathrm{~g}} \rightarrow{ }^{4} \mathrm{~T}_{1 \mathrm{~g}}(F)\left(\mathrm{v}_{2}\right)$ and respectively. The transitions correspond to the typical octahedral geometry of the complexes. 
The electronic spectra of Manganese (II) complexes display the d-d transition bands in the region 17,000-14,800 cm$-1,19,200-17,900 \mathrm{~cm}^{-1}$ and $26,300-25,300 \mathrm{~cm}^{-1}$. This transitions may be assigned to the ${ }^{6} \mathrm{~A}_{1 \mathrm{~g}} \rightarrow{ }^{4} \mathrm{~T}_{1 \mathrm{~g}}(\mathrm{G}),{ }^{6} \mathrm{~A}_{1 \mathrm{~g}} \rightarrow{ }^{4} \mathrm{~T}_{2 \mathrm{~g}}(\mathrm{G})$ and ${ }^{6} \mathrm{~A}_{1 \mathrm{~g}} \rightarrow{ }^{4} \mathrm{~A}_{1 \mathrm{~g}},{ }^{4} \mathrm{E}_{\mathrm{g}},(\mathrm{G})$ respectively. The transitions correspond to the octahedral geometry of the complexes ${ }^{14}$.

The electronic spectra of iron(II) complexes display the d-d transition broad bands in the region $14,700-12,300 \mathrm{~cm}^{-1}$ and $27,300-25,100 \mathrm{~cm}^{-1}$. The latter high energy band might be charge transfer in nature and low energy band may be assigned to the spin-allow transition ${ }^{5} \mathrm{~T}_{2 \mathrm{~g}} \rightarrow{ }^{5} \mathrm{E}_{\mathrm{g}}$ which correspond to the typical octahedral geometry of the complexes.

The electronic spectra of cobalt(II) complexes display the d-d transition bands in the region $9,350-8,400 \mathrm{~cm}^{-1}, 20,000-18,600 \mathrm{~cm}^{-1}$ and $28,100-26,500 \mathrm{~cm}^{-1}$. The first two bands may be correspond to ${ }^{4} \mathrm{~T}_{1 \mathrm{~g}}(\mathrm{~F}) \rightarrow{ }^{4} \mathrm{~T}_{2 \mathrm{~g}}(\mathrm{~F}) \mathrm{v}_{1}$ and ${ }^{4} \mathrm{~T}_{1 \mathrm{~g}}(\mathrm{~F}) \rightarrow{ }^{4} \mathrm{~T}_{1 \mathrm{~g}}(\mathrm{P}) \mathrm{v}_{3}$ transitions respectively. These bands are the characteristics of high spin octahedral Co(II) complexes. However $v_{2}$ band is not observed because of its proximity to strong $v_{3}$ transitions.

The electronic spectra of nickel(II) complexes display the d-d transition bands in the region $11,900-8,500 \mathrm{~cm}^{-1}, 20,700-13,200 \mathrm{~cm}^{-1}$ and $26,200-19,500 \mathrm{~cm}^{-1}$. This transitions may be assigned to the ${ }^{3} \mathrm{~A}_{2 \mathrm{~g}} \rightarrow{ }^{3} \mathrm{~T}_{2 \mathrm{~g}}(\mathrm{~F}) \mathrm{v}_{1},{ }^{3} \mathrm{~A}_{2 \mathrm{~g}} \rightarrow{ }^{3} \mathrm{~T}_{1 \mathrm{~g}}(\mathrm{~F}) \mathrm{v}_{2}$ and ${ }^{3} \mathrm{~A}_{2 \mathrm{~g}} \rightarrow{ }^{3} \mathrm{~T}_{1 \mathrm{~g}}(\mathrm{p}) \mathrm{v}_{3}$ respectively. These transitions reveal that the nickel complexes possess an octahedral geometry and $\mathrm{D}_{4 \mathrm{~h}}$ symmetry.

For the $\mathrm{Cu}$ (II) complexes with $\mathrm{D}_{4}$ h symmetry, three spin allowed transitions ${ }^{2} \mathrm{~B}_{1 \mathrm{~g}} \rightarrow{ }^{2} \mathrm{~A}_{1 \mathrm{~g}}$ $\left(v_{1}\right),{ }^{2} \mathrm{~B}_{1 \mathrm{~g}} \rightarrow{ }^{2} \mathrm{~B}_{2 \mathrm{~g}}\left(\mathrm{v}_{2}\right)$ and ${ }^{2} \mathrm{~B}_{1 \mathrm{~g}} \rightarrow{ }^{2} \mathrm{E}_{\mathrm{g}}\left(\mathrm{v}_{3}\right)$ are possible but the electronic spectra of $\mathrm{Cu}$ (II) complexes display two bands at $14,367 \mathrm{~cm}^{-1}, 21,448 \mathrm{~cm}^{-1}$ and $14,198 \mathrm{~cm}^{-1}, 21,290 \mathrm{~cm}^{-1}$ respectively. There should be third transition but we could not observe the same which may be due to very close energy values of different states. Absence of any spectral band below $10000 \mathrm{~cm}^{-1}$ rule out the possibility for tetrahedral structure of the present complexes are also suggestive for distorted octahedral geometry of the complexes.

\section{Thermogravimetric analysis}

\section{Thermogravimetric analysis of $\mathrm{Mn}(\mathrm{II}), \mathrm{Fe}(\mathrm{II}), \mathrm{Co}(\mathrm{II}), \mathrm{Ni}(\mathrm{II})$ and $\mathrm{Cu}(\mathrm{II})$ complexes}

The thermograms of this group of metal complexes show three stages decomposition (Table 5). All the metal complexes do not show weight loss below $120^{\circ} \mathrm{C}$, it indicates the absence of lattice water in the metal complexes.

Table 5. Thermo analytical results of metal complexes of Schiff base ligand $\mathrm{L}$ and ligand $\mathrm{L}_{1}$

\begin{tabular}{cccc}
\hline Compounds & $\begin{array}{c}\left.\text { Stage-I [140-210 }{ }^{\circ} \mathrm{C}\right] \\
\text { Mass lose } \\
\text { Obs. (Calc.) }\end{array}$ & $\begin{array}{c}\left.\text { Stage-II [210-400 }{ }^{\circ} \mathrm{C}\right] \\
\text { Mass lose } \\
\text { Obs. (Calc.) }\end{array}$ & $\begin{array}{c}\left.\text { Stage-III [400-900 }{ }^{\circ} \mathrm{C}\right] \\
\text { Mass lose } \\
\text { Obs. (Calc.) }\end{array}$ \\
\hline$\left[\mathrm{Mn}(\mathrm{L})_{2} .2 \mathrm{H}_{2} \mathrm{O}\right]$ & $3.81(3.85)$ & $87.67(87.92)$ & $8.12(8.20)$ \\
{$\left[\mathrm{Fe}(\mathrm{L})_{2} .2 \mathrm{H}_{2} \mathrm{O}\right]$} & $3.82(3.85)$ & $87.58(87.83)$ & $8.47(8.53)$ \\
{$\left[\mathrm{Co}(\mathrm{L})_{2} \cdot 2 \mathrm{H}_{2} \mathrm{O}\right]$} & $3.80(3.84)$ & $88.41(88.49)$ & $7.84(7.99)$ \\
{$\left[\mathrm{Ni}(\mathrm{L})_{2} \cdot 2 \mathrm{H}_{2} \mathrm{O}\right]$} & $3.81(3.83)$ & $90.19(90.12)$ & $6.20(6.25)$ \\
{$\left[\mathrm{Cu}(\mathrm{L})_{2} \cdot 2 \mathrm{H}_{2} \mathrm{O}\right]$} & $3.86(3.81)$ & $88.04(87.96)$ & $8.37(8.43)$ \\
{$\left[\mathrm{Mn}\left(\mathrm{L}_{1}\right)_{2} \cdot 2 \mathrm{H}_{2} \mathrm{O}\right]$} & $3.69(3.74)$ & $88.16(88.27)$ & $8.41(8.54)$ \\
{$\left[\mathrm{Fe}\left(\mathrm{L}_{1}\right)_{2} \cdot 2 \mathrm{H}_{2} \mathrm{O}\right]$} & $3.78(3.74)$ & $88.14(88.19)$ & $8.22(8.28)$ \\
{$\left[\mathrm{Co}\left(\mathrm{L}_{1}\right)_{2} \cdot 2 \mathrm{H}_{2} \mathrm{O}\right]$} & $3.70(3.72)$ & $88.64(88.73)$ & $7.65(7.75)$ \\
{$\left[\mathrm{Ni}\left(\mathrm{L}_{1}\right)_{2} \cdot 2 \mathrm{H}_{2} \mathrm{O}\right]$} & $3.64(3.72)$ & $90.32(90.41)$ & $6.12(6.07)$ \\
{$\left[\mathrm{Cu}\left(\mathrm{L}_{1}\right)_{2} \cdot 2 \mathrm{H}_{2} \mathrm{O}\right]$} & $3.66(3.70)$ & $90.79(90.94)$ & $8.09(8.19)$ \\
\hline & Loss of two & Loss of two Schiff & \\
\hline $\mathrm{Assignment}$ & coordinated water & base ligand molecules & Metal oxide \\
& molecules & & \\
\hline
\end{tabular}


The first stage decomposition is obtained in the temperature range $140-210{ }^{\circ} \mathrm{C}$. The \% weight loss in this range is corresponds the loss of two coordinated water molecules ${ }^{15-17}$. The second stage decomposition is obtained in the temperature range $210-400{ }^{\circ} \mathrm{C}$. The $\%$ weight loss in this range is corresponds $\%$ weight loss of two Schiff base ligands.

The third stage decomposition range is obtained in the temperature range $400-900{ }^{\circ} \mathrm{C}$. The $\%$ weight loss in this range is corresponds $\%$ weight loss of metal oxide residue.

\section{Thermogravimetric analysis of Cr(III) complexes}

The thermograms of all $\mathrm{Cr}(\mathrm{III})$ metal complexes show two stage decompositions are listed in Table 6. All the metal complexes do not show \% weight loss below $205{ }^{\circ} \mathrm{C}$ suggest the absence of coordinated and/or lattice water molecule/molecules.

Table 6. Thermo analytical results of $\mathrm{Cr}(\mathrm{III})$ complexes of Schiff base ligand $\mathrm{L}$ and ligand $\mathrm{L}_{1}$

\begin{tabular}{lccc}
\hline \multirow{2}{*}{ Compounds } & {$\left[<205^{\circ} \mathrm{C}\right]$} & Stage-I $\left[205-400{ }^{\circ} \mathrm{C}\right]$ & Stage-II $\left[400-900{ }^{\circ} \mathrm{C}\right]$ \\
\cline { 2 - 4 } & Mass Lose & Mass Lose & Mass Lose \\
& $\begin{array}{c}\text { Obs. (Calc.) } \\
{\left[\mathrm{Cr}(\mathrm{L})_{3}\right]}\end{array}$ & $\begin{array}{c}\text { Obs. (Calc. }) \\
\text { Obs. (Calc.) }\end{array}$ & $5.79(5.83)$ \\
{$\left[\mathrm{Cr}\left(\mathrm{L}_{1}\right)_{3}\right]$} & Not Observed & $95.36(95.48)$ & $5.59(5.65)$ \\
Assignment & $\begin{array}{c}\text { Not Observed } \\
\text { Absence of }\end{array}$ & $\begin{array}{c}95.49(95.62) \\
\text { coss of three Schiff } \\
\text { base ligand } \\
\text { molecules }\end{array}$ & Metal Oxide \\
\hline
\end{tabular}

The first and second stage decomposition in the thermogram curves shows the removal of three Schiff base ligands.

The decomposition temperatures $\left(>250^{\circ} \mathrm{C}\right)$ of the metal complexes indicate that they are thermally quite stable, suggesting strong metal-ligand bonding ${ }^{18}$. All the metal complexes show further weight loss beyond $250{ }^{\circ} \mathrm{C}$, which may be due to the weight loss of organic matter (ligand), leaving metal(II) or metal(III) oxide as the final product of the thermal decomposition ${ }^{19}$.

\section{Antibacterial activity}

In recent years, nitrogen heterocyclic compounds have gained importance on account of their varied types of biological activities ${ }^{20-22}$ pyrazole derivatives have been reported to possess antidiuretic ${ }^{23}$, antihelminthic ${ }^{24}$, hypoglycaemic, fungicidal, antituberculotic ${ }^{25}$, antineoplastic ${ }^{26}$ and antifertility ${ }^{27}$ activities.

The effect of the ligands and their metal complexes in the growth media were investigated by standard microbiological parameters. Concentration of the test compounds were kept constant $(500 \mathrm{ppm})$ during all the experiments. The bacterial, fungal and yeast cultures were maintained on nutrient-agar, potato dextrose-agar and YEDP culture-tubes (slants) respectively and were sub cultured every fortnight and stored at $0-5{ }^{\circ} \mathrm{C}$ temperature.

The compounds were tested in vitro for the antibacterial activity against Bacterial [Escherichia coli, Bacillus subtilis and $S$. aureus] and fungal [A.niger] and yeast $[S$. cerevisiae] cultures with both ligands and their metal complexes using Agar cup assay method. 
The degree of effectiveness was measured by determining the diameters of the zone of inhibition caused by the compounds. Effectiveness was classified into three zones on the bases of their diameter of zone of inhibition.

$\begin{array}{ll}+++ & : \text { Most effective } \\ ++ & : \text { Moderate effective } \\ + & : \text { Slightly effective } \\ - & : \text { Non effective }\end{array}$

Most of the compounds were active against both gram (-) negative and gram (+) positive bacteria. The results are presented in Table 7 .

Table 7. Antimicrobial activity of Schiff base ligand $\mathrm{L}$, ligand $\mathrm{L}_{1}$ and their metal complexes

\begin{tabular}{lccccc}
\hline \multicolumn{1}{c}{ Compounds } & E. coli & B. subtillis & S. aureus & S. cerevisiae & A. niger \\
\hline$[\mathrm{L}]$ & + & + & + & + & + \\
{$\left[\mathrm{Cr}(\mathrm{L})_{3}\right]$} & ++ & ++ & + & ++ & + \\
{$\left[\mathrm{Mn}(\mathrm{L})_{2}\left(\mathrm{H}_{2} \mathrm{O}\right)_{2}\right]$} & ++ & + & ++ & + & ++ \\
{$\left[\mathrm{Fe}(\mathrm{L})_{2}\left(\mathrm{H}_{2} \mathrm{O}\right)_{2}\right]$} & ++ & ++ & ++ & ++ & + \\
{$\left[\mathrm{Co}(\mathrm{L})_{2}\left(\mathrm{H}_{2} \mathrm{O}\right)_{2}\right]$} & ++ & ++ & + & ++ & ++ \\
{$\left[\mathrm{Ni}(\mathrm{L})_{2}\left(\mathrm{H}_{2} \mathrm{O}\right)_{2}\right]$} & + & ++ & ++ & ++ & ++ \\
{$\left[\mathrm{Cu}(\mathrm{L})_{2}\left(\mathrm{H}_{2} \mathrm{O}\right)_{2}\right]$} & + & ++ & ++ & ++ & + \\
{$[\mathrm{L}]$} & + & + & + & + & + \\
{$\left[\mathrm{Cr}\left(\mathrm{L}_{1}\right)_{3}\right]$} & ++ & + & ++ & + & ++ \\
{$\left[\mathrm{Mn}\left(\mathrm{L}_{1}\right)_{2}\left(\mathrm{H}_{2} \mathrm{O}\right)_{2}\right]$} & ++ & ++ & + & + & ++ \\
{$\left[\mathrm{Fe}\left(\mathrm{L}_{1}\right)_{2}\left(\mathrm{H}_{2} \mathrm{O}\right)_{2}\right]$} & ++ & +++ & ++ & ++ & ++ \\
{$\left[\mathrm{Co}\left(\mathrm{L}_{1}\right)_{2}\left(\mathrm{H}_{2} \mathrm{O}\right)_{2}\right]$} & ++ & ++ & + & ++ & +++ \\
{$\left[\mathrm{Ni}\left(\mathrm{L}_{1}\right)_{2}\left(\mathrm{H}_{2} \mathrm{O}\right)_{2}\right]$} & ++ & +++ & + & +++ & + \\
{$\left[\mathrm{Cu}\left(\mathrm{L}_{1}\right)_{2}\left(\mathrm{H}_{2} \mathrm{O}\right)_{2}\right]$} & + & ++ & ++ & + & ++ \\
\hline
\end{tabular}

The Schiff base ligand $\mathrm{L}$ without metal is slightly effective against all strains of microorganisms.

- The $\mathrm{Cr}$ (III) metal complex is slightly effective against S. aureus \& A. niger and moderately effective against $E$. coli, $B$. subtilis and $S$. cerevisiae.

- The Mn(II) metal complexes are slightly effective against B. subtilis \& S. cerevisiae and moderately effective against $E$. coli, $S$. aureus and $A$. niger.

- The Fe(II) metal complex is slightly effective against $A$. niger and moderately effective against $E$.coli, B. subtilis $S$. aureus and $S$. cerevisiae.

- The Co(II) metal complex is slightly effective against $S$. aureus and moderately effective against $E$. coli, $B$. subtilis, $S$. cerevisiae and A. niger.

- All the Ni(II) metal complexes are moderately effective against E. coli, B. subtilis, $S$. aureus, $S$. cerevisiae and $A$. niger.

- The $\mathrm{Cu}(\mathrm{II})$ metal complexes are slightly effective against E. coli \& A. niger and moderately effective against $B$. subtilis, $S$. aureus and $S$. cerevisiae.

The Schiff base ligand $\mathrm{L}_{1}$ without metal is slightly effective against all strains of microorganisms.

- $\quad$ The $\mathrm{Cr}(\mathrm{III})$ metal complex is slightly effective against $B$. subtilis \& S. cerevisiae and moderately effective against $E$. coli, $S$. aureus and A. niger.

- $\quad$ The $\mathrm{Mn}(\mathrm{II})$ metal complexes are slightly effective against $S$. aureus \& S. cerevisiae and moderately effective against $E$. coli, B. subtilis and A. niger. 
- The Fe(II) metal complexes are moderately effective against E.coli, S. aureus $S$. cerevisiae \& A. niger and mostly effective against $B$. subtilis.

- The Co(II) metal complex is slightly effective against $S$. aureus when moderately effective against $E$. coli, $B$. subtilis \& S. cerevisiae and mostly effective against $A$. niger.

- The Ni(II) metal complexes are slightly effective against $S$. aureus \& A. niger when moderately effective against $E$. coli and mostly effective against $B$. subtilis and $S$. cerevisiae.

- $\quad \mathrm{The} \mathrm{Cu}(\mathrm{II})$ metal complexes are slightly effective against E.coli \& S. cerevisiae when moderately effective against $B$. subtilis, S. aureus and A. niger.

\section{Conclusion}

On the basis of these results obtained for elemental analysis, infrared spectra, electronic spectra, TGA analysis and magnetic susceptibility measurements the following structures are proposed for the complex compounds of both ligands.

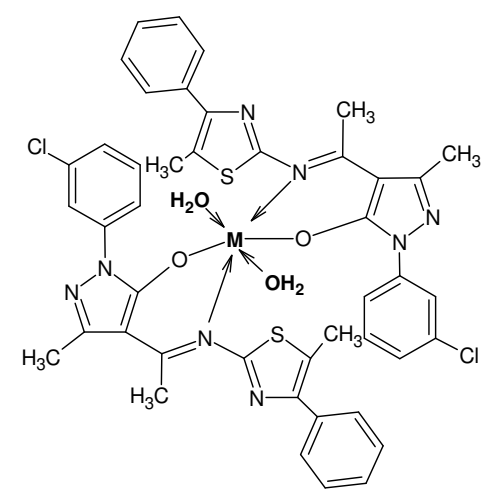

Where $\mathrm{M}=\mathrm{Mn}(\mathrm{II}), \mathrm{Fe}(\mathrm{II}), \mathrm{Co}(\mathrm{II}), \mathrm{Ni}(\mathrm{II})$ and $\mathrm{Cu}(\mathrm{II})$

Figure 9. Structure of Complexes of the ligand

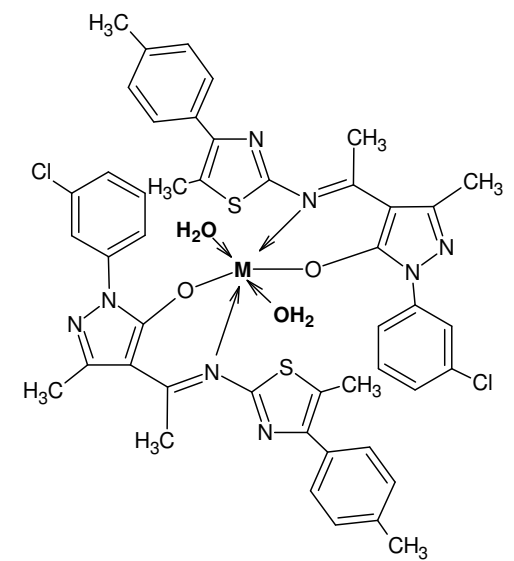

Where $\mathrm{M}=\mathrm{Mn}(\mathrm{II}), \mathrm{Fe}(\mathrm{II}), \mathrm{Co}(\mathrm{II}), \mathrm{Ni}(\mathrm{II})$ and $\mathrm{Cu}(\mathrm{II})$

Figure 10. Structure of Complexes of the ligand $\mathrm{L}$

The synthesized metal complexes in comparison to the uncomplexed Schiff base ligand were screened for their antibacterial activity against pathogenic bacteria species (Escherichia coli, Bacillus subtilis, S. aureus, A. niger and S. cerevisiae). The activity of the Schiff base 
complexes became more pronounced when coordinated with metal ions. The biological activity of the complexes follow the order $\mathrm{Co}(\mathrm{II})=\mathrm{Ni}(\mathrm{II})>\mathrm{Mn}(\mathrm{II}), \mathrm{Fe}(\mathrm{III}), \mathrm{Cu}(\mathrm{II})$.

\section{Acknowledgments}

The authors wish to express their gratitude to Dahod Anaj Mahajan Sarvjanik Education Society for laboratory facilities, Principal N.V Patel Science College, V.V Nagar, Anand, Zydus Cadila, Ahmedabad for spectral analysis.

\section{References}

1. Metzger J V, The chemistry of Heterocyclic Compounds, Thiazole and Its Derivatives, A Series of Monographs, Wiley, Chichester, 1979, 34.

2. Troutman H D and Long L M, J Am Chem Soc., 1948, 70, 3436-3439.

3. Fink B E, Mortenson D S, Stauffer S R, Aron Z D and Katzenellenbogen J A, Chem Biol., 1999, 6, 205-219.

4. Geary W J, Coord Chem Rev., 1971, 7, 81-112.

5. Hamming $\mathrm{M} \mathrm{C}$ and Foster N G, Interpretation of Mass Spectra of Organic Compounds; Academic Press: New York, USA, 1972, 422-430.

6. Silverstein $\mathrm{R} M$ and Webster $\mathrm{F} X$, Spectrometric Identification of Organic Compounds, Wiley, New Delhi, India, 2007, 144-216.

7. Bellamy L J, The infrared Spectra of Complex Molecules, $3^{\text {rd }}$ Ed., Chapman and Hall, London, 1975, 52.

8. Patel I A and Thaker B T, Indian J Chem., 1999, 38A, 427-433.

9. Rana A K and Shah J R, Indian J Chem., 1981, 20A, 615-617.

10. Nakamoto K, Infrared spectra of Inorganic and coordination Compounds, John Willey, New York, USA, 1963, 167.

11. Adams D M, Metal-Ligand and Related Vibrations- a Critical Survey of the Infrared and Raman Spectra of Metallic and Organometallic Compounds, Edward Arnold, London, 1967, 310.

12. Okafor E C, J Inorg Nucl Chem., 1980, 42, 1155-1159.

13. Rahman S M F, Ahmad J and Haq M M, J Inorg Nucl Chem., 1973, 35, 1011-1013.

14. Dutta R L and Syamal A, Element of Magneto Chemistry, Sultan Chand \& Company Ltd, Ramnagar, New Delhi, 1982.

15. Modi C K, Patel S H and Patel M N, J Therm Anal Cal., 2007, 87(2), 441-448.

16. Mohamed, G G and Abd El-Wahab Z H, J Therm Anal Cal., 2003, 73, 347-359.

17. Mohamed G G, Nour El-Dien F A and El-Gamel Nadia E A, J Therm Anal Cal., 2002, 67, 135-146.

18. Jagtap S B, Chikate R C, Yemul O S, Ghadage R S and Kulkarni B A, J Therm. Anal Cal., 2004, 78, 251-262.

19. Modi C K, Spectrochemica Acta., Part A: Molecular and Biomolecular Spectroscopy, 2009, 71(5), 1741-1748.

20. Garg H G, J Med Chem., 1972, 15(4), 446-447.

21. Gopalkrishna J, Ravi A and Patel C C, Bull Chem Soc Japan, 1967, 40, 791-799.

22. Naik N and Ramappa P G, Asian J Chem., 1995, 7, 860-868.

23. Garg H G and Kaur N, J Med Chem., 1972, 15(5), 554-555.

24. Garg H G and Arora V J, J Pharm Sci., 1972, 61, 130-132.

25. Behnisch R, Mietzch F and Schmidt H, Am Rev Tuberc., 1950, 61, 1-7.

26. Garg H G and Sharma R A, J Pharm Sci., 1970, 59, 348-353.

27. Garg H G and Sharma R A, J Med Chem., 1970, 13(3), 579-581. 


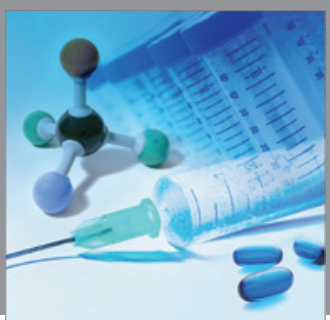

International Journal of

Medicinal Chemistry

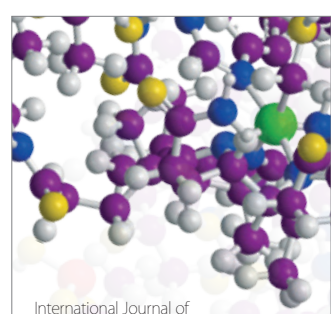

Carbohydrate Chemistry

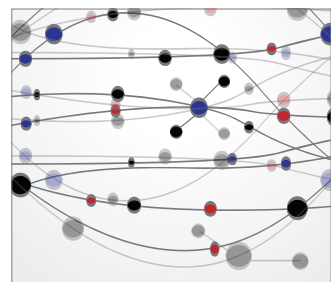

The Scientific World Journal
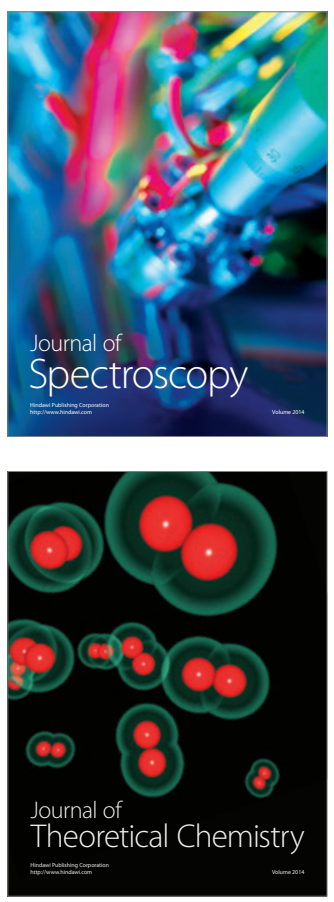
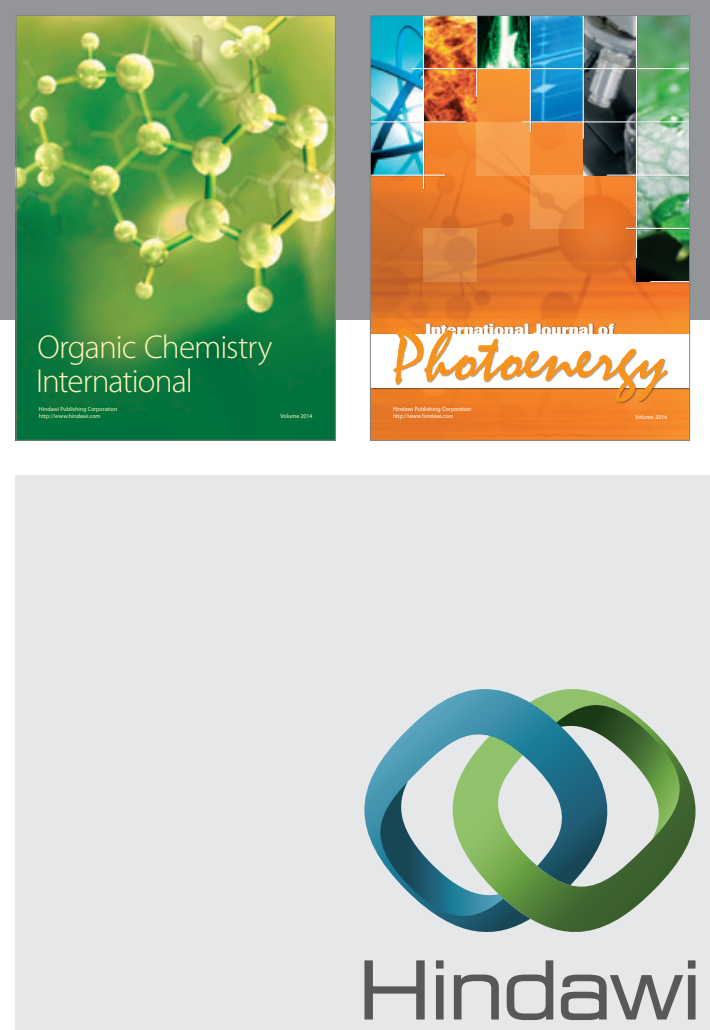

Submit your manuscripts at

http://www.hindawi.com
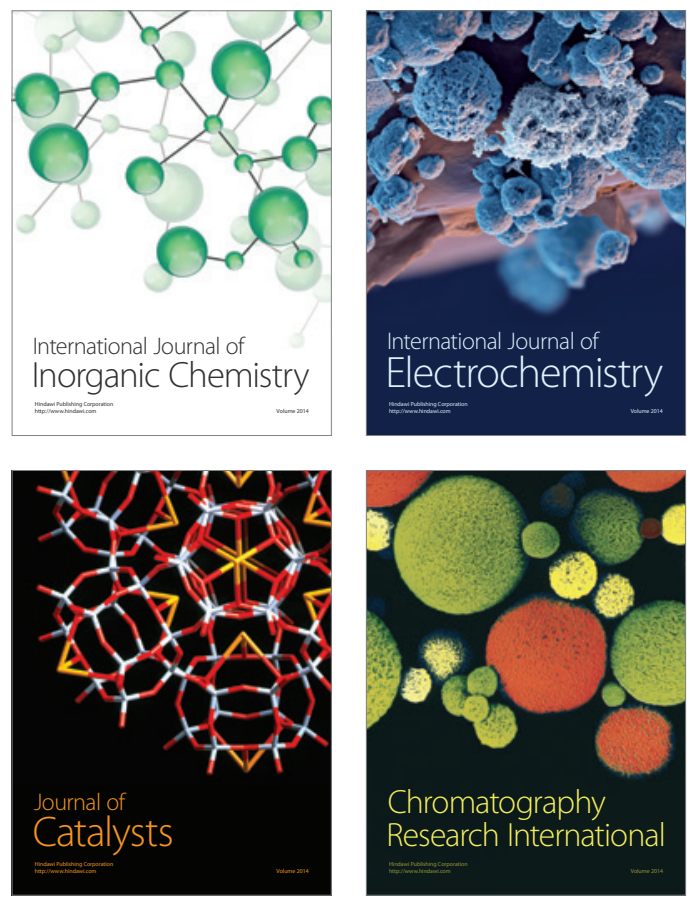
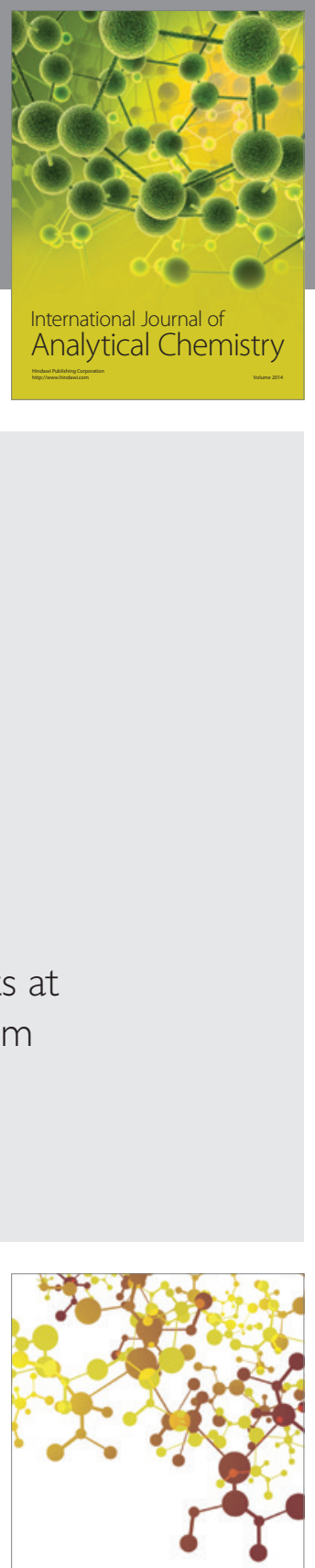

Journal of

Applied Chemistry
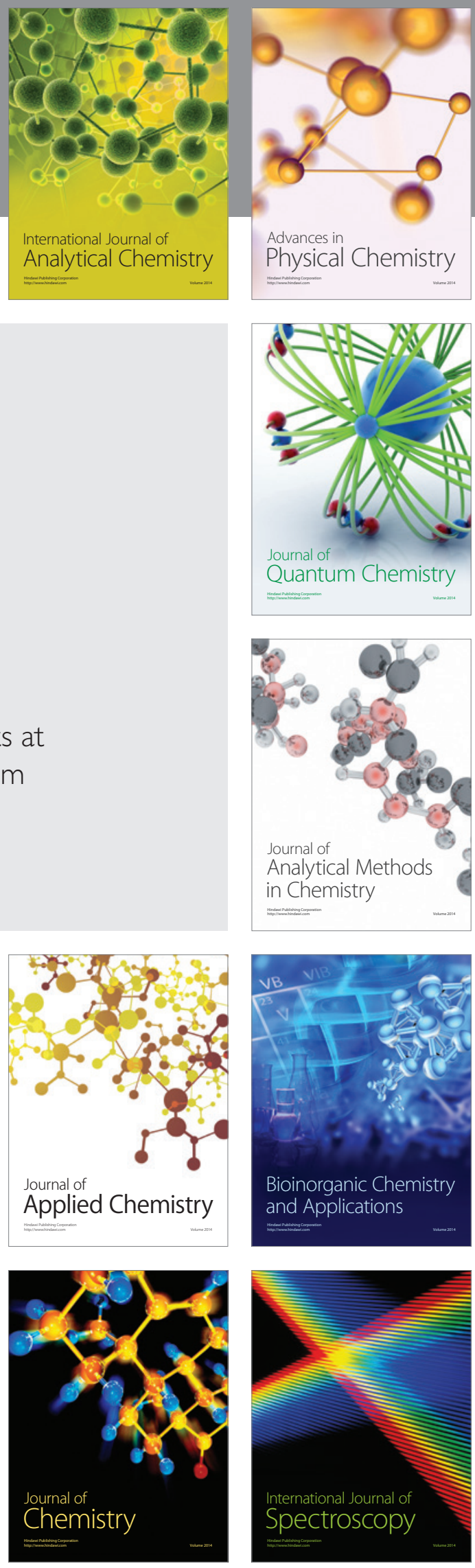